\title{
Authorship of YB Mangunwijaya on Roro Mendut Novel
}

\author{
${ }^{1}$ Irsasri, ${ }^{2}$ St. Y. Slamet, ${ }^{3}$ Retno Winarni, ${ }^{4}$ E. Nugraheni Eko Wardani \\ 1irsabipa@yahoo.co.id, ${ }^{2}$ styslamet.fkip.uns.ac.id, ${ }^{3}$ retnowinarni@ staff.uns.ac.id, \\ ${ }^{4}$ nugraheniekowardani_99@yahoo.com \\ 1,2,3,4,Universitas Sebelas Maret Surakarta
}

\begin{abstract}
Author and his fictional work are homologous. Roro Mendut novel by YB. Mangunwijaya is the evident of homologous. Background of life of Y.B. Mangunwijaya as missionary and his educational experience from he studied to graduate as civil engineer and his impelentation talent of his skill are reflected in his novel. This research aims to show homologous between fictional work and author in aesthetical expression of Y.B. Mangunwijaya through Roro Mendut novel. The discussion of the analysis is performed using theoretical framework of Ian Watt with sociological approach. The result shows some "Javanese" universal expressions in educational ways in Roro Mendut novel. Ideology about common people life emerges in the novel. Several myths and understanding of people to the fatalism and tragic occurrences had been changed by Y.B. Mangunwijaya as common sense and fair occurrences. The result shows that the authorship of Y.B. Mangunwijaya in the reflection of Rara Mendut novel is orientation to the poor.
\end{abstract}

Keywords: YB. Mangunwijaya, authorship, homology, orientation to the poor, Roro Mendut.

\section{INTRODUCTION}

Rara Mendut Novel (1992) is historical anthology trilogy novel by Y.B. Mangunwijaya. The trilogy consists of three parts entitled Rara Mendut, Genduk Duku, and Lusi Lindri. The story presented is semi historical roman as developed from Babad Tanah Jawi story (old Javanese text) "Rara Mendut" and some other chosen sources. The trilogy tells about way of living of a beautiful woman in the reign of Sultan Agung, king of Kasultanan Mataram in $17^{\text {th }}$ century. It is a grief story with kraton background using classical ending like the previous tragedy of love story; Ken Arok-Ken Dedes, Ki Ageng Mangir-Pambayun, or Pangeran Pabelan-Sekar Kedaton in the reign of Kasultanan Pajang. On the other side, the power of Rara Mendut story lies on its ending. Placing story on three central characters; Mendut-Pranacitra-Wiraguna, the novel replays legendary tragedy of love in the early building of the Mataram kingdom.

Y.B. Mangunwijaya presents the story with fully life values in trilogy Rara Mendut, Genduk Duku, and Lusi Lindri. Social cultural condition is inseperable from the philosophy of author life as missionary. This research aims to reveal Mangunwijaya authorship life and its relation to his expression in the works Trilogyi Rara Mendut, Genduk Duku, and Lusi Lindri novel. The goal is to find relation or homology of Mangunwijaya authorship life through social cultural index in his trilogy. This research uses theoretical framework of authorship as stated by Ian Watt[1]. 


\section{DISCUSSION \\ Authorship of Y.B. Mangunwijaya}

A literary work studied using literary sociology started from author orientation. Literary work is reflection of time as represented by author's worldview, not as individual but as member of society. Sociology of author is interaction and interpretation from living background and of and social situation of the author.

Sociology of author, and literary intuition, problems dealing with here is economical base of literary product, social background, and ideology of the author as reflected in any activities beyond the literary works, for every author is social member, social creature. Biography of author is main source, but this study is able to be broadening to the circumstance of the author living place and origin. Due to that, information of family background, nature of educational and working background of author will be beneficial in disclosing the problems of the novel[1]. This theoretical framework will help to disclose the homology of Mangunwijaya authorship and his work Rara Mendut.

Literature is reflection of society as it is influenced by historical condition. Therefore, literature is a reflection from its cultural circumstance and emerges as dialectic text between author and his society. The social situation is an explanation of historical dialectic as developed in literary work. Author's social can cultural influence roles in defining the living characterization in the novel and the messages author wants to deliver to the reader through his literary work.

\section{Biography of Y.B. Mangunwijaya}

Yusuf Bilyarta Mangunwijaya was born in Ambarawa, 6 May 1929. He is the eldest of twelve sons of Yulianus Sumadi and Serafin Kandaniyah. His children name was Bilyarta. Yusuf is the Baptist name, while Mangunwijaya was his grandfather's name, a tobacco farmer. His father was an elementary school teacher in Magelang in Dutch colonial era. Mangunwijaya spent his childhood in Magelang, Jawa Tengah. He graduated his Elementary school in HIS Fransiscus Xaverius in Magelang in 1943, Junior High School (SMP) in Yogyakarta in 1947, then He studied in Sekolah Teknik Mesin (STM) Jetis, Yogyakarta in 1943 and graduate in 1947.

During his study in STM Jetis, Mangunwijaya followed Kinrohosi or military obligation without payment for social figures like village officials and lower workers. The activities were held by Japanese soldiers in Balapan yard, Yogyakarta. At that time, Mangunwijaya started to be interested in studying World history and philosophy[2].

In 1944, STM Jetis, the school where Mangunwijaya studied was dismissed and was modified into Republic of Indonesia struggle headquarter. Mangunwijaya was still young at that time. He joined in the action of stealing Japanese cars' soldiers in order to help Republic Indonesia soldiers' struggle in defeating Japanese occupation. In 1945 young Mangunwijaya set himself to be Tentara Keamanan Rakyat (TKR) Batalyon X division III. He was sent by his commander in military dormitory in Vrederburg fortress, then in military dormitory in Kotabaru, Yogyakarta. As a soldier, Mangunwijaya joined the war in Ambarawa, Magelang and Mranggen. Even, he also became ransom deliver to Danyon (Komandan Batalyon), Major Soeharto in Mranggen front, Semarang post independent era.

One year later, in conducive nation safety situation, Mangunwijaya continued his school for his school in STM Jetis dismissed. The same year, Mangunwijaya was involved in the peaceful process of independence sovereign by joining the Student Soldier (Tentara Pelajar). In the time as the Student Soldier, he had duties as driver of War Commander, Sri Sultan Hamengkubuwono IX when inspecting troops. In 1947 Mangunwijaya graduated from 
STM Jetis in time of Clash I or Dutch military aggression I. After that, Mangunwijaya joined Tentara Pelajar Brigade XVII as Student Soldier Commander in Kedu Batalyon. One year later, in 1948, Mangunwijaya experienced his education by entering SMU-B Santo Albertus in Malangm East Java. In this school, his spiritual heart gloomed. He was then elected as representative of Catholic Youth to visit celebration of independence of Republic of Indonesia in Malang city yard. In the place Mangunwijaya heard the speech of Major Isman, a patriot of Indonesian independence struggle who was then very influential to Mangunwijaya.

Mangunwijaya accomplished his education at SMU-B Santo Albertus Malang in 1951. His feeling to be a missionary has delivered him to continue his education to Seminari Menengah Kotabaru, Yogyakarta, the school for educating candidate for priest who will lead and serve catholic followers. Mangunwijaya studied there for one year and continue to Seminari Menengah Santo Petrus Kanisius, Mertoyudan, Magelang. His intelligence and definite for his calling as missionary had helped him to accomplish his middle seminary to higher seminary school at Sekolah Institut Filsafat and Teologi Santo Paulus di Kotabaru. One of his lecturer was Mgr. Albertus Soegijapranata, SJ, the first indigene bishop of Indonesia and national hero of Republic Indonesia. It was the pride situation felt by Mangunwijaya to accomplish his spiritual education. On 8 September 1959, Mangunwijaya was inaugurated to be missionary by Semarang Great Bishop, Mgr. Albertus Soegijapranata, SJ[3].

Being a missionary was not enough by Mangunwijaya to serve people. After his inauguration as missionary, Mangunwijaya continued his study at Architecture Technique, Istitut Teknologi Bandung (ITB). It was reasonable for Mangunwijaya to continue his education at ITB for his interest in art and architecture fields can be applied. The brilliant of Mangunwijaya in his study had delivered him to continue his architecture education to Rheinisch Westfaelische Technische Hochschule, Aachen, Germany. It was the time for Mangunwijaya to move to Germany. In 1966 he graduated his architecture education and returned to Indonesia.

Returning from Germany, Mangunwijaya became parish missionary head in Saint Theresia church, Salam village, Magelang. He was familiar to be called Romo Mangun. His calling and spirit of mission in serving people were not merely to catholic followers but also to other religion followers. During his early pastoral mission, Romo Mangun started to build brotherhood with other religious figures like Abdulrahman Wahid and Gedong Bagoes Oka.

Romo Mangun began to manage his service broadly, obeyed and developed his thought to others. Professionally, as architect, he became adjunct lecturer in architecture department, faculty of engineering, Gadjah Mada University, Yogyakarta. As hard worker, Romo Mangun started to write article for Indonesia Raya and Kompas newspaper. His writing was thematic in religion, culture, and technology. Besides that Romo Mangun also wrote short story and novel. His writings mostly obtained great appreciation from domestic and foreign readers. In 1975 Romo Mangun won Piala Kincir Emas, in his short story held by Radio Netherlands.

This eldest son of Yulianus Sumadi and Serafin Kamdaniyah was also famous as icon of historical novel writer in Javanese context with his cultural senses. It was proven with two magnum opus novels, Burung-burung Manyar (1982) (achieved South East literary award, Ramon Mangsasai in 1996) and his trilogy novel Roro Mendut, Genduk Duku, Lusi Lindri (1983-1987).

All of Romo Mangun life spent to service work either for pastoral and social activities. Room Mangun passed away on 10 February 1999. He passed away after giving speech in seminar entitled "Meningkatkan Peran Buku dalam Upaya Membentuk Masyarakat Indonesia Baru" in Hotel Le Meridien, Jakarta. 


\section{Author as Missionary}

Feeling as missionary stimulated Mangunwijaya to express his works totally. His spirit to state option for the poor had dominated his way of thinking.

\section{Moral Principle and Humanity}

Romo Mangun worked hard to serve others as missionary and civil. He entered any sides of life with high appreciation to human dignity, which were identical to poverty but had to have highest level of all creatures in the world. Most of Indonesian people were still in poverty level, they lived below poverty level and feudal and colonial atmosphere so that the experienced suffer for long time. The people illustrated by Mangunwijawa were called as the ills, marginal, suppressed, forgettable, tortured, and left behind[2].

This reality of humanity was full of unfair treatment. Mangunwijaya as missionary deliver the situation into Rara Mendut novel as follow.

Pasukan berkuda lagi. Pajak baru barangkali? Para nelayan bergelut mati-matian dengan ombak buas dan angin liar; setiap malam harus mengorbankan waktu, ketika orang lain menikmati ranjang. Jenis orang-orang berseragam merah berpelesir kencana itu hanya datang membawa tombak dan keris. Cuma minta ini, merampok itu. Kalau begitu apa bedanya: raja dengan benggolan penyamun?[3]

Mangunwijaya stated that the unfair system is forestry system made by people. The world master has made law without humanity. They and the armed people group has conducted arbitrary and sacrificed humanity sense for marginal people.

Humanity soul and attention of Romo Mangun to social problems since his youth is getting supported by people around him. Supported by Dr. Soedjatmoko, Romo Mangun followed his short course about humanity as Fellow of Aspen Institute for Humanistic Studies, Aspen, Colorado, AS. Manifestation of humanity principle of Romo Mangun had been known widely since 1980-1986 when assisting inhabitant of Kali Code riverside when they were threatened to be kicked out of their settlement.

Romo Mangun together with the inhabitants performed to stop eating in refusing the removal settlement. His empathy to the marginal in social problem and unfair treatment was going to increase when in 1986-1994, government planned to build waduk Kedung Ombo. Romo Mangun never stopped to assist the Kedung Ombo settlement as the victim of the removal action.

\section{Social Thought}

Through humanism works, Romo Mangun gave physical inheritance in novel, architecture buildings, and references books. Option for the poor (not always in economical meaning) and the marginal were very significant. His strict critic about awakening from condescending, inlanders labour, were delivered through many ways, even felt sarcastic.

Some humanistic works and service of Romo Mangun obtained wide appreciation internationally. One of them came from The Aga Khan Award, a highest award for architectural works in the developing countries for Kali Code architecture in 1992, which then established him as Indonesian modern architect father. Award and admittance to his works and attention to the poor and humanity did not stimulate him to stop his activities. Romo Mangun began to pay attention to the future of children education. In 1994 Romo Mangun built laboratory for Dinamika Edukasi Dasar (DED). This is the model DED education implemented in SD Kanisius Mangunan, Ka.lasan, Sleman, Yogyakarta. Romo Mangun believed that proper elementary education would born intellectuali generation[3]. 
In architect besides physical building, Romo Mangun donated design science into story in novels. Room Mangun ever found an invitation to plan Kowilhan II headquarter around Gedung Agung area. In his literary works of Romo Mangun, technique and beauty of architect are illustrated well. Each readers had their own perception in reading his literary works. Rahmanto gave comment to the novel of Burung-Burung Manyar. He sees the novel as an architectural building consist of many parts. The first part (year 1934-1944) is the children time of the writer, and it functions as introduction. The second part (year 1945-1950) is the inner conflict against any lust in finding self identity. The third (year 1968-1978) is the solving problem[4].

Real donation of Romo Mangun in way of thinking and social work was seen from his activities after returning from his study in Aachen Jerman. He directly returned to Yogyakarta and formulated intellectual ideas as catholic missionary who graduated his education from secular country, Germany. He found his context in Indonesia as inspiration. Yogyakarta did not appear as locality symbol, but as globalization with its soul and spirit of universality.

In 1980 Romo Mangun retired from lecturing in Architecture engineering department, Gadjah Mada University, Yogyakarta after 12 years teaching. Whereas, his position as lecturer in the oldest and biggest college in Indonesia was most wanted by scholars who was eager to be nobles. Responding the situation, Romo Mangun answered "for me architecture does not have crucial problem. I shall take care problems people rarely pay attention to, like Kali Code problem which is dealing with humanity."

\section{Philosophy of the Author}

Romo Mangunwijaya wrote Rara Mendut from his own initiation. He wrote the novel based on his own consciousness which was possibly ignited from his eagerness to awaken Javanese way of thinking from boundaries of myths. As an individual who was taken care in western tradition which is identical to critics, Romo Mangunwijaya, in his novel, tried to perform demystification to his fictional characters. The character of Rara Mendut who was so far understood by most of Javanese people as beautiful woman, soft, but fatalistic, had been modified by Mangunwijaya into "common woman". The portrayal of her beauty which was initially physical then was modified into inner beauty: smooth and fatalistic attitudes were modified into strong and spiritual woman in her struggle.

Besides the portrayal of Rara Mendut character, Mangunwijaya as missionary also deconstructed the discourse dealing with death process of the main character. In Javanese, the death process of Rara Mendut was believed as suicide; on the other hand the death of Rara Mendut in the novel was modified into "chivalrous" conduct. In Rama Mangun point of view, Mataram era was Islamic era. Therefore, based on logic and religiosity consciousness, the character of Rara Mendut was portrayed as the person who had absorbed Islamic values, and one of the values was strict prohibition for any Islamic followers to end their life wasting and humiliated in suicide. Therefore, Rara Mendut did not stab her keris which was used to kill Pranacitra to her own chest, but she used it to fight against the strength Wiraguna. Finally, the death approached Rara Mendut, but her death was caused by her attitudes and struggles.

Mangunwijaya authorship philosophy was appropriate to Koentjaraningrat[5] view which was devided into religion system, value and way of life systems, religion ritual. As missionary, Mangunwijaya did not separate his authorship idea from human relation to The Creator, God. He portrayed belief system of men to God in some expressions like "Hyang Maha Pengasih", "Allah Yang Maha Bijaksana", "Allah Subhanahu wa ta'aala". 


\begin{abstract}
"Syukurlah Hyang Maha Pengasih menggerakkan garwa-padmi dan Ni Sekar untuk menyerahkan si Mendut padanya." [3]

...bukankah itu dapat menjadi titipan Allah Yang Maha Bijaksana juga, yang tidak kalah nikmat, sumber syukur dan pemekaran diri seorang wanita? [3]
\end{abstract}

Mangunwijaya also paid attention to social values and their view of life. Option for the poor or lower class people is able to be seen from Mangunwijaya expression when portrayed fishermen who have to struggle to conquer the sea for their effort to earn money for daily life. As the poor people, the efforts of the fishermen are sometimes success but sometimes failed.

Namun akibatnya para abang nelayanlah yang harus bertempyr mencari selamat dalam huru-hara air asin yang kacau itu. Tak banyaklah nelayan tua dengan pemuda itu membawa hasil usaha sepanjang malam untuk dijual, menegakkan periuk si ibu dapur[3]

The values system and way of life of the fishermen who never surrender becomes the philosophy of Mangunwijaya authorship. This philosophy also appears in the fictional expression in[6]. The quotation below show the consistency of Mangunwijaya in giving attention to the poor.

Satu-satunya percobaan meringankan beban hati kekasihnya hanyalah nasihat warisan para nelayan,"marwita margining maruta". Angin dorong dari belakang maupun angin lawan dari muka, keduanya dapat dimanfaatkan agar perahu tetap maju[6].

The belief system expressed show philosophy of relationship between men and God through any signs given by God in the universe. Mangunwijawa just wants to show that any human activities have been guaranteed by God, the creator. Men just only understand and comprehend what, where, why, when, and how the signs are. This philosophy also determines that men do not need to be afraid in life, for God guarantees everything in the universe. Men have to appreciate others and nature, make any productive efforts for their pride and dignity as social creatures.

The following philosophy is religious ritual. Mangunwijaya implicitly presented religious ritual which is natural to the inhabitants. He presented "Javanese religion" ritual which is considered ancient and has been understood comprehensively by traditional society.

Di pantai Selatan, di suatu kuala kecil, sangat dini pagi, fajar yang menyingsing tanpa ajakan ramai menerangi gubug Pranacitra dan Mendut, dan dengan caranya sendiri mengajak bangun pagi. Pelan-pelan Mendut bangkit dan sambil mengikat rapi kembali rambut terurai, wanita itu mendekat ke laut, berlutut, mencium tanah, dan sangat pelan seolah menari kedua tangannya naik, saling mengatup di muka wajahnya yang menghening, dan bersembahlah seluruh jiwa raga. Maka bersama-sama dengan merpati-merpati laut yang penuh syukur menikmati sinar-sinar pertama sang surya, sehingga cahaya putih bulu-bulu sayap mereka dengan angkasa perunggu emas dan sapuan biru nila dini merupakan lukisan yang berhakekat kidung, melayanglah doa sang Wanita, sang Bumi yang bahagia telah menerima Biji sang Petani, "Ya, Allah! Malam telah lalu dan fajar menyingsing fajar baru, Betapa rindu kami padaMu, karena tanpa matahari serba buta menggapai-gapai hamba-hambaMu..., [3] 
Expression and quotation above proved that the great influence of Mangunwijaya life background as missionary who had attention and empathy to the poor. Here, the relation of authorship and literary work is homologous. The real life of Mangunwijaya who was identical and optional to the poor expresses in the fictional characters who have wholly dignity, who are able to set appropriate relation to others, nature, and God. Mangunwijaya shows simplicity and low profile in his authorship.

\section{CONCLUSION}

The result shows that authorship or Y.B. Mangunwijaya in creating trilogy novel Rara Mendut, Genduk Duku, and Lusi Lindri is sincerely reflection of his living experience in watching, observing, and empathy as missionary to young generation who is now lack of social attitude in their social life. Mangunwijaya creating Rara Mendut character as the main character in Rara Mendut does not show her feminine, but as the manifestation from woman struggle against patriarchal domination. The authorship of Y.B. Mangunwijaya in Rara Mendut, shows philosophy of life as manifested in Moral Principle and Humanity, social thought, and religion ritual. Mangunwijaya always gives motivation, hope, and ways of life to lower class people through modification and demystification in his fictional character, Rara Mendut. Thus, the common philosophy of Rama Mangun is struggle for and having option for the poor. That is the relationship and homology of Mangunwijaya authorship and his literary work, Rara Mendut.

\section{BIBLIOGRAPHY}

[1] I. Watt, The Rise of the Novel. London: Penguin Books, 1968.

[2] Sindhunata, Mengenang Y.B. Mangunwijaya: Pergulatan Intelektual dalam Era Kegelisahan. Yogyakarta: Kanisius, 1999.

[3] Y. B. Mangunwijaya, Rara Mendut. Jakarta: Gramedia, 2009.

[4] B. Rahmanto, Y.B. Mangunwijaya: Karya dan Dunianya. Jakarta: Grasindo, 2001.

[5] Koentjaraningrat, Pengantar Ilmu Antropologi. Jakarta: Rineka Cipta, 2000.

[6] L. P. U. Airlangga, Serat Pranacitra-rara Mendut dan Trilogi Novel Karya Y. B. Mangunwijaya: Sebuah Telaah Intertekstualitas. UNAIR: FISIP, 1993. 